\title{
Karakteristik Klinis Pasien Trombosis Sinus Venosus Serebral (TSVS) di Ruang Rawat Inap Neurologi Rumah Sakit Hasan Sadikin Bandung
}

\author{
Lisda Amalia \\ Departemen Neurologi Fakultas Kedokteran Universitas Padjadjran/RSUP dr. Hasan Sadikin Bandung
}

\begin{abstract}
Abstrak
Latar Belakang dan Tujuan: Trombosis sinus venosus serebral (TSVS) merupakan penyakit akibat oklusi struktur vena intrakranial, termasuk sinus serebral, vena korteks, dan bagian proksimal vena jugularis. Keterlambatan diagnosis dan terapi dapat mengakibatkan terjadinya komplikasi seperti infark berdarah bahkan kematian. Tujuan penelitian ini adalah untuk mengetahui karakteristik klinis pasien TSVS yang diagnosisnya telah dikonfirmasi melalui pemeriksaan DSA.

Metode: Penelitian ini bersifat deskriptif observasional retrospektif. Pada pasien yang telah didiagnosis TSVS di Bagian Neurologi Rumah Sakit Hasan Sadikin Bandung periode Juni 2015 sampai November 2017.

Hasil: Terdapat 33 subjek dengan rentang usia 40-49 tahun (24,2\%) dan mayoritas adalah perempuan sebanyak 22 orang $(66,7 \%)$. Faktor resiko terbanyak adalah infeksi 8 orang $(24,2 \%)$, dan kondisi protrombotik sebanyak 6 orang $(18,2 \%)$. Gejala klinis terbanyak adalah nyeri kepala yaitu 27 orang $(81,8 \%)$. Lokasi sinus yang tersering mengalami trombosis adalah sinus transversus pada 28 orang dengan gejala mayoritas nyeri kepala. Kadar D-Dimer ditemukan meningkat dengan rata-rata $1,21 \mathrm{mg} / \mathrm{L}$.

Simpulan: Pasien TSVS terjadi pada perempuan dengan rentang usia dekade pertengahan dan faktor resiko terbanyak adalah infeksi. Nyeri kepala merupakan gejala paling sering. Lokasi trombosis mayoritas terjadi pada sinus transversus dan ditemukan peningkatan D-Dimer.
\end{abstract}

Kata kunci: TSVS, DSA, karakteristik klinis

JNI 2020, 9 (2): 71-7

\section{Clinical Characteristics of Cerebral Venous Sinus Thrombosis (CVST) Patients in Neurology Ward Hasan Sadikin General Hospital Bandung}

\begin{abstract}
Background and Objective: CVST is an entity caused by intracranial vein, including cerebral sinuses, cortical vein and proximal part of the jugular vein. A delay in diagnosing and treating can result in brain infarct with hemorrhagic transformation, even death. The goal of this study is to learn the clinical characteristics of patients with CVST that had been confirmed by DSA.

Method: This was a retrospective observational descriptive study and subjects were hospitalized patients which had been diagnosed CVST in Neurology ward Hasan Sadikin General Hospital from June 2015 to November 2017. Results: there was 33 subjects with most (22 patient/66.7\%) being women between $40-49$ years old. In this study the most frequently found risk factor was infection in 8 subjects $(24.2 \%)$, prothrombotic conditions in 6 subjects $(18.2 \%)$. The clinical manifestations were mainly headache in 27 subjects $(81,8 \%)$. The sinus most often involved was the transverse sinus (28 subjects) with the clinical manifestation being headache. D-dimer levels were also increased with mean $1.21 \mathrm{mg} / \mathrm{dl}$.

Conclusion: CVST patients are mostly in women at the midle age of decade, with infection being the most frequent risk. Headache was the most frequent clinical manifestation. Location of thrombosis were more often found on the transverse sinus and D-Dimer level was increased.
\end{abstract}

Key words: clinical characteristic, CVST, DSA

JNI 2020, 9 (2): 71-7

This article is licensed under a

Creative Commons Attribution-NonCommercial-ShareAlike 4.0 International License.

CLisda Amalia (2020) under the CC-BY-NC-SA license 


\section{Pendahuluan}

Trombosis sinus venosus serebral (TSVS) merupakan penyakit akibat oklusi struktur vena intrakranial, termasuk sinus serebral, vena korteks, dan bagian proksimal vena jugularis. Hal ini menyebabkan berbagai manifestasi klinis akut dan kronik. Tehnik pemeriksaan penunjang neuroimaging diperlukan untuk membantu menegakkan diagnosis TSVS. $^{1}$ Keterlambatan diagnosis dan terapi dapat mengakibatkan terjadinya komplikasi seperti infark berdarah bahkan kematian. TSVS merupakan kasus yang agak jarang terjadi dengan angka kejadian kurang dari $1 \%$. TSVS lebih sering ditemukan pada pasien dengan usia kurang dari 50 tahun terutama wanita, pasien dengan trombofilia dan wanita hamil atau yang menggunakan obat kontrasepsi hormonal. ${ }^{1-4}$ Sebuah studi retrospektif dari rumah sakit di Arab Saudi periode 1985 sampai 1994 memperkirakan kejadian kurang dari 10 kasus per juta orang per tahun, studi prospektif dari 122 pasien antara tahun 2001 sampai 2004 di Isfahan, Iran, melaporkan 12,3 kasus per juta orang per tahun, studi multisenter retrospektif di Belanda dari 94 pasien selama tahun 2008 sampai 2010 melaporkan 13,2 kasus per juta orang per tahun, dan studi prospektif yang baru dari Hamadan, Iran, dari 151 kasus antara 2009 sampai 2015 melaporkan 13,5 kasus per juta per tahun. ${ }^{1}$ Suatu studi di Australia (Adelaide) dari 7 rumah sakit umum pada tahun 2005 sampai 2011 yaitu 105 kasus orang dewasa, mewakili 15,7 kasus per juta penduduk setiap tahunnya dengan distribusi seks yang hampir sama ( $52 \%$ perempuan). Dengan penelitian ini mencerminkan diagnostik dan strategi manajemen yang lebih baik. ${ }^{1-4}$ Tanda dan gejala klinis TSVS sangat bervariasi, dapat bersifat akut, sub akut ataupun kronis. Tanda dan gejala klinis terutama adalah nyeri kepala, dapat disertai kejang, akan tetapi mungkin juga tidak spesifik sehingga dalam menegakkan diagnosis berdasarkan gambaran radiologis sedini mungkin sangat penting dan penatalaksanaan spesifik dapat diberikan secepat mungkin. ${ }^{2-6}$ Awal terjadinya TSVS disebabkan karena kondisi protrombotik yang bisa disebabkan karena penyakit atau kondisi tertentu seperti yang sudah disebutkan dalam faktor resiko TSVS. Kondisi protrombotik adalah kondisi yang tidak normal dimana terjadi peningkatan faktor koagulasi darah yang menyebabkan risiko terjadinya trombosis. Digital Subtraction Angiography (DSA) merupakan suatu teknik diagnostik invasif yang digunakan untuk menggambarkan dengan jelas pembuluh darah vena. Meskipun demikian DSA masih dianggap pemeriksaan baku emas. Ketika ada kecurigaan secara klinis pada pasien TSVS, namun dari hasil pemeriksaan magnetic resonanse venography (MRV) atau computed tomography venography (CTV) tidak ditemukan kelainan, maka DSA adalah pilihannya., ${ }^{3,7}$ Penelitian tentang TSVS belum pernah dilakukan di Indonesia, sehingga peneliti tertarik untuk mengetahui bagaimana karakteristik klinis TSVS yang telah dikonfirmasi dengan pemeriksaan DSA untuk membantu menegakkan diagnosis, sehingga tatalaksana dapat cepat diberikan dan mencegah kejadian komplikasi serta rekurensi. Penelitian ini diharapkan dapat memberikan gambaran karakteristik tanda dan gejala klinis pasien TSVS.

\section{Metode}

Penelitian ini adalah penelitian deskriptif observasional bersifat retrospektif dari rekam medis pasien yang telah didiagnosis TSVS di ruang rawat inap Neurologi Rumah Sakit Hasan Sadikin Bandung. Dilakukan pengambilan data dari rekam medis pasien yang dilakukan secara total sampling dengan diagnosis akhir TSVS berdasarkan hasil pemeriksaan DSA yang dirawat maupun datang ke poli saraf Rumah Sakit Hasan Sadikin Bandung, data dilengkapi dengan wawancara ulang pasien saat kontrol ke poli atau menghubungi pasien dengan telepon. Penelitian telah mendapatkan persetujuan dari Komite Etik dan Penelitian Kesehatan RSUP dr. Hasan Sadikin Bandung. Data yang terkumpul dikelompokan, diedit dan diproses dengan menggunakan program SPSS versi 25 windows.

\section{Hasil}

Rekam medis yang memenuhi kriteria inklusi dan ekslusi dimulai dari tahun 2015 sampai dengan bulan November 2017 diperoleh total 
sampel sebanyak 33 pasien. Berdasarkan umur terlihat bahwa sebagian besar pasien TSVS terjadi di rentang usia 40-49 tahun sebanyak 8 orang $(24,2 \%)$. Karakteristik berdasarkan jenis kelamin terlihat bahwa wanita lebih banyak mengalami TSVS yaitu sebanyak 22 orang $(66,7 \%)$ dibanding dengan laki-laki 11 orang $(33,3 \%)$. Karakteristik berdasarkan faktor risiko didapatkan dari rekam medis dan anamnesa ulang pasien, faktor risiko infeksi lebih banyak didapatkan yaitu sebanyak 8 orang $(24,2 \%)$ terdiri dari infeksi daerah telinga, rongga sinus dan mastoid, diikuti kondisi protrombotik 6 orang $(18,2 \%)$ terdiri dari defisiensi protein $\mathrm{C}$ dan S serta yang lainnya dengan kadar D-dimer meningkat belum diketahui penyebabnya, terapi hormon 2 orang $(6,1 \%)$ yang disebabkan karena penggunaan kontrasepsi oral, penyakit sistemik 2 orang $(6,1 \%)$ terdiri dari pasien yang menderita penyakit SLE, keganasan 2 orang $(6,1 \%)$ terdiri dari pasien dengan riwayat tumor payudara dan limfoma kemudian penyakit hematologi 1 orang (3,0\%) yaitu pasien yang menderita Autoimmune Hemolytic Anemia (AIHA) yang disebabkan dari penyakit SLE yang sedang diderita oleh pasien TSVS. Karakteristik berdasarkan tanda dan gejala klinis dapat dilihat bahwa gejala klinis nyeri kepala gejala yang paling sering ditemukan oleh penderita TSVS yaitu sebanyak 27 orang $(81,8 \%)$, diikuti hemiparesis sebanyak 11 orang $(33,3 \%)$, vertigo sebanyak 9 orang $(27,3 \%)$, tinitus sebanyak 2 orang $(6,1 \%)$, diplopia 1 orang $(3,0 \%)$, gangguan penglihatan 1 orang $(3,0 \%)$ dan kejang 1 orang $(3,0 \%)$ (lihat tabel 1$)$.

\section{Tabel 1 Karakteristik Klinis Pasien TSVS}

\begin{tabular}{lll}
\hline Karakteristik klinis & $\mathrm{n}$ & $(\%)$ \\
\hline Usia & 2 & 6 \\
$<20$ tahun & 6 & 18,1 \\
$20-29$ tahun & 6 & 18,1 \\
$30-39$ tahun & 8 & 24,2 \\
$40-49$ tahun & 7 & 21,2 \\
$50-59$ tahun & 4 & 12,1 \\
$>60$ tahun & & \\
Jenis kelamin & 11 & 33 \\
Laki - laki & 22 & 66,7 \\
Perempuan & & \\
Faktor risiko & 6 & 18,2 \\
Kondisi protrombotik & 2 & 6,1 \\
Terapi hormon & 8 & 24,2 \\
Infeksi & 1 & 3 \\
Penyakit hematologi & 2 & 6,1 \\
Penyakit sistemik (contoh: SLE) & 2 & 6,1 \\
Keganasan & & \\
\hline
\end{tabular}

Tabel 2. Gambaran DSA Pasien TSVS

\begin{tabular}{lll}
\hline DSA & $\mathrm{N}=33$ & $\%$ \\
\hline Sinus transversus & 28 & 84,8 \\
Sinus kavernosus & 5 & 15,1 \\
Vena interna & - & - \\
Sinus sagitalis superior & - & - \\
Sinus sagitalis inferior & - & - \\
Sinus sigmoid & - & - \\
Sinus rektus & - & - \\
\hline
\end{tabular}

Tabel 3. Karakteristik Klinis Pasien TSVS Berdasarkan Hasil DSA

\begin{tabular}{llll}
\hline Gejala dan Tanda Klinis & \multicolumn{3}{c}{ DSA } \\
\cline { 2 - 4 } & $\begin{array}{l}\text { S. Transversus }(\mathbf{n}=\mathbf{2 8}) \\
\mathbf{n}(\mathbf{\%})\end{array}$ & $\begin{array}{l}\text { S. Kavernosus }(\mathbf{n}=\mathbf{5}) \\
\mathbf{n}(\mathbf{\%})\end{array}$ & $\mathbf{N}(\%)$ \\
\hline Nyeri kepala & $23(82,1 \%)$ & $4(80 \%)$ & $27(81,8 \%)$ \\
Hemiparesis & $9(31,1 \%)$ & $2(40 \%)$ & $11(33,3 \%)$ \\
Parese saraf Kranial & $5(17,8 \%)$ & $2(40 \%)$ & $7(21,2 \%)$ \\
Diplopia & $1(3,5 \%)$ & - & $1(3 \%)$ \\
Vertigo & $6(21,4 \%)$ & $6(21,4 \%)$ & $9(27,3 \%)$ \\
Gangguan penglihatan & $1(3,5 \%)$ & - & $1(3 \%)$ \\
Tinitus & $2(7,1 \%)$ & - & $2(6,1 \%)$ \\
Kejang & $1(3,5 \%)$ & - & $1(3 \%)$ \\
\hline
\end{tabular}


Tabel 4. Hasil Pemeriksaan Laboratorium Pasien TSVS

\begin{tabular}{llll}
\hline Laboratorium & Rata-rata & Rentang & Nilai Normal \\
\hline Hemoglobin & $13,00 \mathrm{~g} / \mathrm{dL}$ & $8,6-17,6 \mathrm{~g} / \mathrm{dL}$ & $13,5-17,5 \mathrm{~g} / \mathrm{dL}$ \\
Hematokrit & $39,47 \%$ & $26,6-51,00 \%$ & $40-52 \%$ \\
Leukosit & $7,700 / \mathrm{mm} 3$ & $4,800-10,300 / \mathrm{mm} 3$ & $4500-11,000 / \mathrm{mm} 3$ \\
Trombosit & $308,000 / \mathrm{mm} 3$ & $225,000-527,000 / \mathrm{mm} 3$ & $150,000-450,000 / \mathrm{mm} 3$ \\
LED & $14,00 \mathrm{~mm} / \mathrm{jam}$ & $4-23 \mathrm{~mm} / \mathrm{jam}$ & $0-20 \mathrm{~mm} / \mathrm{jam}$ \\
PT & $14,31 \mathrm{detik}$ & $9,6-36,2$ detik & $8,3-12,3$ detik \\
APTT & $32,52 \mathrm{detik}$ & $21,00-71,6$ detik & $16,4-36,4$ detik \\
INR & 1,14 & $0,53-3,63$ & $0,83-1,17$ \\
Fibrinogen & $332,35 \mathrm{mg} / \mathrm{dL}$ & $199,2-541 \mathrm{mg} / \mathrm{dL}$ & $200-400 \mathrm{mgdL}$ \\
D-Dimer & $1,21 \mathrm{mg} / \mathrm{L}$ & $0,2-4,29 \mathrm{mg} / \mathrm{L}$ & $<0,55 \mathrm{mg} / \mathrm{dL}$ \\
\hline
\end{tabular}

Karakteristik Klinis Pasien TSVS Berdasarkan Gambaran DSA

Pada penelitian ini yang ditemukan trombosis sinus transversus pasien TSVS sebanyak 28 orang $(84,8 \%)$ dan sinus kavernosus sebanyak 5orang $(15,1 \%)$ (lihat tabel 2). Karakteristik gejala dan tanda klinis dengan gambaran DSA pada pasien TSVS dengan trombosis di sinus transversus dapat dilihat keluhan nyeri kepala sering ditemukan, diikuti hemiparesis, vertigo dan parese saraf kranial. Sedangkan pada trombosis di sinus kavernosus keluhan nyeri kepala juga banyak ditemukan, diikuti vertigo, hemiparesis dan parese saraf kranial (lihat tabel 3).

\section{Karakteristik Hasil Pemeriksaan Laboratorium Pasien TSVS}

Pada hasil laboratorium yang dilakukan sebelum ditegakkannya diagnosis TSVS dapat dilihat hasil yang menonjol adalah peningkatan kadar D-Dimer pasien dengan rata-rata yaitu 1,21 $\mathrm{mg} / \mathrm{L}$, seperti pada tabel 4 .

\section{Pembahasan}

Usia penderita TSVS terjadi pada rentang usia 40-49 tahun (24,2\%). Hasil ini sesuai dengan penelitian pada tahun 2014 yang mengatakan TSVS lebih banyak terjadi pada usia kurang dari lima puluh tahun. ${ }^{8}$ Pada karakteristik berdasarkan jenis kelamin didapatkan angka kejadian TSVS pada wanita lebih besar dibanding pria yaitu sebesar $66,7 \%$. Ini sesuai dengan penelitian sebelumnya yang mengatakan 3 dari 4 orang penderita TSVS adalah wanita, karena kondisi yang berkaitan dengan kehamilan, masa nifas dan penggunaan kontrasepsi oral. ${ }^{9}$ Pada penelitian ini didapatkan pasien dengan faktor risiko gangguan hormon yang disebabkan karena penggunaan kontrasepsi oral. Penelitian lain mengatakan bahwa wanita yang menggunakan kontrasepsi oral akan meningkatkan risiko terjadinya TSVS. ${ }^{10}$ Penggunaan kontrasepsi oral akan meningkatkan faktor prokoagulan VII, X, XII, XIII dan mereduksi faktor antikoagulan, protein $\mathrm{S}$ dan antitrombin yang menyebabkan kondisi protrombotik pada pasien. ${ }^{10}$ Bila dilihat dari karakteristik berdasarkan faktor risiko dapat dilihat bahwa infeksi daerah rongga sinus dan mastoid lebih banyak terjadi, diikuti oleh faktor risiko kondisi protrombotik. Hal ini disebabkan karena kurangnya kesadaran dan ketidaktahuan masyarakat tentang pencegahan infeksi serta pentingnya pengobatan penyakit infeksi yang menjadi faktor risiko terjadinya TSVS. Satu penelitian mengatakan dari 7 orang sukarelawan dengan kadar C-Reactive Protein (CRP) yang tinggi menyebabkan peningkatan signifikan terhadap von Willebrand factor, fragmen protrombin 1 dan 2, D-Dimer serta penghambat aktivator plasminogen tipe 1 . Sebuah penelitian lain mengatakan bahwa CRP akan menghambat ekspresi aktivator plasminogen pada jaringan endotel yang akan merangsang adhesi trombosit serta pertumbuhan trombus. ${ }^{11}$ Faktor risiko keganasan juga didapatkan pada penelitian ini. 
Pada penelitian yang dilakukan Graham dkk mengatakan bahwa pembentukan reaktan pada fase akut, metabolisme protein yang abnormal, nekrosis dan perubahan hemodinamis dapat berkontribusi terhadap aktivasi koagulasi pada pasien dengan keganasan. Terdapat dua interaksi antara sel malignan dengan sistem hemostasis, yang pertama kemampuan untuk memproduksi dan menghasilkan prokoagulan serta sitokin inflamasi, yang kedua interaksi langsung dengan sel darah lainnya. Aktifitas prokoagulan pada sel tumor menyebabkan pembentukan deposit fibrin dan akan mengaktifasi faktor X secara independen. Sitokin inflamasi akan mempengaruhi sistem koagulasi di vaskular, sebagai contoh tumor necrosis factor- $\alpha$ (TNF- $\alpha)$ dan interlekuin- $1 \beta$ (IL-1 $\beta$ ) yang dapat menginduksi tissue factor (TF) dan mengurangi aktifasi protein $\mathrm{C}$ sebagai antikoagulan. Tissue factor ini diproduksi sebagai respon inflamasi yang akan membentuk kompleks dengan faktor VII dan menginisiasi proses koagulasi dengan mengaktifkan faktor IX dan X. ${ }^{12}$ Faktor risiko oleh karena penyakit sistemik sindroma lupus eritematosus juga ditemukan pada penelitian ini, data ini didapatkan dari rekam medis. Penelitian lain mengatakan beberapa mekanisme yang berkontribusi pada terjadinya TSVS, yang pertama karena terjadinya kerusakan pada sel endotel yang disebabkan karena imune complex induced vasculitis yang diperkirakan berperan penting terjadinya Neuropsychiatric Systemic Lupus Erythematosus (NPSLE) termasuk TSVS. ${ }^{13}$ Mekanisme kedua karena adanya antibodi antiphospolipid (APL) yang merupakan penyebab lain TSVS pada SLE. Interaksi antara sel endotel dengan APL akan menghambat fungsi protein $\mathrm{C}$ dan protein $\mathrm{S}$ yang akan menyebabkan terbentuknya trombus. ${ }^{13,14}$

Karakteristik berdasarkan gejala dan tanda klinis menunjukkan bahwa keluhan nyeri kepala lebih banyak dibandingkan keluhan lain yaitu sebanyak $81,8 \%$. Trombus daerah sinus transversus akan menyebabkan gejala berupa hipertensi intrakranial dan paling sering menyebabkan nyeri kepala. Sekitar $90 \%$ pasien dengan trombus vena serebri mengeluhkan nyeri kepala yang menyeluruh maupun terlokalisir. ${ }^{3,15}$ Berikutnya adalah hemiparesis sebanyak $33,3 \%$, trombus pada daerah sinus sagitalis superior dan inferior dapat menyebabkan kelainan motorik dan kejang, karena lokasi lesi yang dekat dengan area motorik dan pusat kejang daerah kortikal-subkortikal. ${ }^{3}$

Trombosis pada sinus transversus akan mengganggu aliran darah dari sinus sagitalis superior dan sinus sagitalis inferior, karena sinus transversus merupakan kelanjutan dari sinus sagitalis superior dan sinus sagitalis inferior. Sehingga trombosis pada sinus transversus bisa menyebabkan gejala yang sama. Gejala gangguan penglihatan disebabkan karena trombus pada sinus tranversus yang akan mengganggu penyerapan cairan otak oleh villi araknoid, karena di sinus transversus banyak terdapat villi araknoid sehingga trombosis pada lokasi tersebut akan mengakibatkan hidrosepalus yang akan mengkompresi nervus II. Keluhan vertigo pada sinus transversus dan sinus kavernosus disebabkan karena lokasi kedua sinus tersebut berdekatan dengan nervus VIII, sehingga bila terjadi trombosis akan menggangu aliran darah balik dari nervus VIII yang akan menyebabkan gangguan sistem keseimbangan, sedangkan gejala tinitus dan kelumpuhan saraf kranial lain disebabkan karena adanya trombus pada vena jugularis interna. ${ }^{3}$ Vena jugularis interna merupakan kelanjutan dari dua cabang sinus tranversus, sehingga trombus pada sinus transversus akan menyebabkan gejala tinitus dan kelumpuhan saraf kranial. Gejala diplopia merupakan tanda dari kelumpuhan saraf penggerak bola mata yang disebabkan karena trombus daerah sinus kavernosus, karena lokasi sinus ini di daerah belakang mata dan dilalui oleh saraf kranial III, IV dan VI. ${ }^{3}$

Trombosis pada sinus transversus juga menyebabkan gejala diplopia karena sinus kavernosus terhubung dengan sinus transversus, sehingga mengganggu aliran darah balik dari sinus kavernosus. Berdasarkan gambaran hasil DSA bisa dilihat bahwa trombosis pada sinus transversus lebih banyak terjadi pada penderita TSVS, yaitu sebanyak 28 orang, diikuti sinus kavernosus sebanyak 5 orang. Hal ini sesuai dengan penelitian terbaru yang dikutip dalam artikel bahwa mendapatkan trombosis lebih 
banyak terjadi pada sinus transversus sebanyak $82 \%$ dan $86 \%$, diikuti sinus sagitalis $52,9 \%$ dan sinus sagitalis superior $35,4 \%$. Dikatakan juga bahwa infeksi selalu menyebabkan trombosis di sinus transversus, sinus kavernosus dan sinus sagitalis. Pada beberapa pasien didapatkan adanya variasi anatomi seperti atresia dan hipoplasia pada sinus transversus kiri. Sekitar 10\% kasus TSVS berhubungan dengan kerusakan dinding pembuluh darah karena adanya inflamasi lokal (sinusitis dan mastoiditis). ${ }^{16,17}$ Sinusitis dan mastoiditis akan menyebabkan terjadinya vaskulitis pada sinus transversus sehingga meningkatkan risiko terjadinya trombosis. Bila dilihat dari kelainan pemeriksaan laboratorium yang menonjol dari pasien TSVS adalah peningkatan kadar D-Dimer dengan rata - rata $1,21 \mathrm{mg} / \mathrm{dL}$. Ini sesuai dengan penelitian sebelumnya yang mengatakan bahwa lebih banyak pasien TSVS memiliki kadar D-Dimer lebih dari $0,5 \mathrm{mg} / \mathrm{dL} \cdot{ }^{18,19}$ Penelitian prospektif yang dilakukan terhadap 35 pasien didapatkan peningkatan kadar D-Dimer pada 34 pasien. Demikian halnya pada penelitian lain didapatkan peningkatan D-Dimer (27 dari 30 pasien). Hasil dari penelitian ini menunjukkan angka sensitivitas 97,2\%, spesifisitas 91,2\% untuk pemeriksaan D-Dimer pada pasien TSVS dan memiliki nilai prediktif yang baik untuk menyingkirkan TSVS (nilai prediktif negatif $99,6 \%$ dan prediktif positif hanya 55,7\%). ${ }^{20}$ Pemeriksaan D-Dimer merupakan acuan awal pemeriksaan laboratorium sebelum melangkah ke pemeriksaan hematologi selanjutnya sesuai dangan faktor risiko yang dimiliki pasien.

\section{Keterbatasan Penelitian}

Penelitian gambaran gejala dan tanda klinis pasien TSVS ini bersifat retrospektif sehingga tidak bisa mendapatkan data yang lengkap, selain itu jumlah populasi yang tidak sesuai. Terdapat rekam medis pasien yang tidak ditemukan. Penelitian ini tidak menilai pengaruh faktor risiko protrombotik dengan kejadian TSVS dan tidak menilai hubungan gejala klinis dengan gambaran klinis.

\section{Simpulan}

Pasien TSVS terjadi pada perempuan dengan rentang usia pertengahan dekade kelima dan faktor resiko terbanyak adalah infeksi. Nyeri kepala dan hemiparesis merupakan gejala paling sering. Lokasi trombosis mayoritas terjadi pada sinus transversus dan ditemukan peningkatan D-Dimer dari hasil pemeriksaan laboratorium.

\section{Daftar Pustaka}

1. Tatlisumak T, Jood K, Putaala J. Cerebral venous thrombosis. Epidemiology in change. Journal of American Heart Association.2016; 47: 2169-70.

2. Einhaupl K, Bousser G, de Bruijnc MTFS, Ferro MJ, Martinellie I, Masuhr F and Stamf J. EFNS guideline on the treatment of cerebral venous and sinus thrombosis. European Journal of Neurology. 2010; 17: 1229-35.

3. Piazza G. Cerebral venous thrombosis. Circulation. 2012; 125: 1704-09.

4. Poon. CS, Chang JK, Swarnkar A, Johnson. MH, Wasenko J. Radiologic diagnosis of cerebral venous thrombosis: pictorial review. AJR 2007; 189: S64-S75.

5. Leach JL, Fortuna RB, Jones BV, GaskillShipley MF. Imaging of cerebral venous thrombosis: current techniques, spectrum of findings and diagnostic. pitfalls radiographics.2006; 26: S19-S43.

6. Rodallec MH, Krainik A, Feydy A, He'lias A, Colombani JM, Julle`s M C, et al. Cerebral venous thrombosis and multidetector $\mathrm{CT}$ angiografi: tips and tricks. Radiographics. 2006; 26: S5-S15.

7. Chiewvit P, Piyapittayanan S, Poungvarin N. Cerebral venous sinus trombosis: diagnostic dillema. Neurology International. 2011; 3: e13: 50-6.

8. Saposnik G, Fernando B, Brown D.R, Bushnell CD, Cucchiara B, Cushman $\mathrm{M}$, et al. Diagnosis and management of cerebral venous thrombosis; a statement 
for healthcare proffesionals from American Stroke Association. Stroke. 2011; 42: 115892.

9. Stam J, Thrombosis of the Cerebral Veins and Sinuses, N Engl J Med. April 2005; 352: 1791-98.

10. Rosendaal FR, Helmerhorst FM, Vandenbroucke. Female hormones and thrombosis. AHA. 2002; 22: 201-10.

11. Tichelaar V, Hanneke C.J, Nelemans K, Meijer K. Infections and inflammatory disease as risk factors for venous thrombosis. Departemen of Hematology, Division of Hemostasis and Thrombosis, University Medical Center Groningen, the Netherlands. ThrombHaemost 2012; 107: 827-37.

12. Caine GJ, Stonelake PS, Gregory YH, Kehoe ST. The hypercoagulable state of malignancy: pathogenesis and current debate. Neoplasia. 2002; 4: 465-73.

13. Wang L, Chen H, Zhang Y, Liu W, Zheng $\mathrm{W}$, Zhang $\mathrm{X}$ et al. Clinical characteristics of cerebral venous sinus thrombosis in patient with Systemic Lupus Erythematosus: A single centre experience in China. Journal of Imunology Research. 2015: 3.

14. Lee M, Kim J, Kang H, Rho H, Nam E, Kim $\mathrm{S}$ et al. Systemic lupus erythematosus Complicated with cerebral venous sinus thrombosis. J Korean Med Sci. 2001; 16: $351-4$.
15. Lubicz B, Neugroschl C, Collignon L, Francois O, Baleriaux D. Is digital substraction angiography still needed for the follow-up of intracranial aneurysms treated by embolisation with detachable coils. Neuroradiology. 2008; 50 (10): 841-8.

16. Fleet J, Birms J, Bhalla A. Cerebral venous thrombosis in adult. Journal Neurologi Disorder Stroke. 2012; 2(2): 1033.

17. Walecki J, Mruk B, Nawrocka E, Laskus, Piliszek, Przelaskowski et al. Neuroimaging of cerebral venous thrombosis-dilemma and the new diagnostic methods. Pol J Radiol, 2015; 80: 368-73.

18. Geyer JD, Gomez CR. Stroke A Practical Approach. Lippincott Williams \& Wilkins. Wolters Kluwer Health. 2009; Page: 308-11.

19. Gijn VJ. Cerebral venous thrombosis: Pathogenesis, presentation and prognosis. Journal of the royal society of medicine. May 2000; 93: 230-33.

20. Saposnik G, Fernando B, Brown D.R, Bushnell CD, Cucchiara B, Cushman $\mathrm{M}$, et al. Diagnosis and management of cerebral venous thrombosis; a statement for healthcare proffesionals from American Stroke Association. Stroke. 2011; 42: 115892. 